\title{
MAKALAH
}

Standar Proses Permendikbud No.65 Tahun 2013

Diajukan sebagai salah satu tugas Mata Kuliah Manajemen Sekolah

\section{Dosen :}

Wahyu Bagja Sulfemi, S.S., M. Pd.

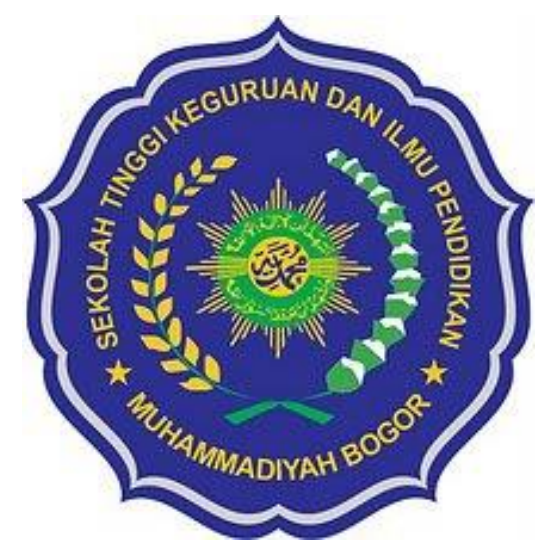

Disusun Oleh :

SRI RAHAYU

NIM 0142S1A018006

\section{PROGRAM STUDI ADMINISTRASI PENDIDIKAN STKIP MUHAMMADIYAH BOGOR}

Jl. Raya Leuwiliang No. 106 Bogor 16640 Telepon : (0251) 8644743, Faks : (0251) 8642847 e-mail :stkipm_bogor@yahoo.com 


\section{A. Pengertian Standar Proses}

1. Standar

Standar adalah suatu norma atau persyaratan yang biasanya berupa suatu dokumen formal yang menciptakan kriteria, metode, proses, dan praktik rekayasa atau teknis yang seragam. (Wikipedia)

2. Proses

Proses adalah serangkaian kegiatan yang diupayakan kepala sekolah bagi kepentingan sekolahnya. Segala proses pendayagunaan semua komponen, baik komponen manusia maupun non manusia, yang dimiliki sekolah dalam rangka mencapai tujuann secara efisien. (Manajemen Sekolah. Sulfemi, Wahyu Bagja). [2019/03]

3. Standar Proses

Standar proses adalah standar nasional pendidikan yang berkaitan dengan pelaksanaan pembelajaran pada satu satuan pendidikan untuk mencapai standar kompetensi lulusan. Proses pembelajaran pada satuan pendidikan diselenggarakan secara interaktif, inspiratif, menyenangkan, menantang memotivasi peserta didik untuk berpartisipasi aktif, serta memberikan ruang yang cukup bagi prakarsa, kreativitas, dan kemandirian sesuaii dengan bakat, minat, dan perkembangan fisik serta psikologis peserta didik. (Perundang-undangan Pendidikan, Sulfemi, Wahyu Bagja) [2016/70]

Berdasarkan Permendikbud Nomor 65 Tahun 2013. Standar Proses dijabarkan sebagai suatu kriteria mengenai pelaksanaan pembelajaran pada satuan pendidikan untuk mencapai Standar Kompetensi Lulusan.

Dari penyusunan tersebut bahwa standar proses merupakan suatu tahapan proses pembelajaran yang menjabarkan mengenai kriteria atau yang dalam Kamus Besar Bahasa Indonesia (KBBI) diartikan sebagai suatu ukuran tertentu yang menjadi dasar penilaian atau penetapan sesuatu, kaitannya dengan pelaksanaan pembelajaran guna mencapai kompetensi lulusan. 
Standar proses merupakan sebuah pedoman atau tahapan langkahlangkah bagi para guru saat mereka memberikan pembelajaran dalam kelas, dengan harapan proses pendidikan yang berlangsung bisa efektif, efesien dan inofatif. Sehingga beberapa target atau kriteria mengenai kompetensi lulusan dapat tercapai dengan sempurna.

Oleh karena itu. Permendikbud nomor 65 tahun 2013 mengamanatkan bahwa proses pembelajaran pada satuan pendidikan harus diselenggarakan secara interaktif, inspiratif, menyenangkan, menentang, memotivasi peserta didik untuk berpartisipasi aktif, serta memberikan ruang yang cukup bagi prakarsa, kreativitas, dan kemandirian sesuai dengan bakat, minat, dan perkembangan fisik serta psikologis peserta didik.

Pada saat inilah keahlian guru sebagai ujung tombak suksesnya proses pendidikan dituntut memiliki keahlian dan kreativitas yang tinggi sehingga mampu mengemas proses pembelajaran sesuai dengan yang diamanatkan. Tentu apabila proses pembelajran mampu menciptakan suasana sebagaimana beberapa tahapan di atas, maka kualitas pendidikan di Indonesia akan mengalami kemajuan yang sangat pesat. Bahkan bukan tidak mungkin proses pendidikan di Indonesia akan mampu menyaingi sistem pendidikan di beberapa negara maju lainnya.

Maka dari itu pada proses penerapan atau taktis pelaksanaan pembelajaran setiap satuan pendidikan dituntut untuk mampu melakukan perencanaan pembelajran dengan baik, sehingga pelaksanaan proses pembelajaran dapat berjalan semaksimal mungkin, serta penilaian proses pembelajaran bisa diarahkan untuk meningkatkan efisiensi dan efektivitas ketercapaian kompetensi lulusan.

\section{B. Pengenalan Tentang Standar Proses Pendidikan}

1. Pengertian Pendidikan

Pendidikan (education) adalah secara semantik berasal dari bahasa Yunani Paidagogia yang berarti pergaulan dengan anak-anak. Pedagogos adalah seorang nelayan atau bujang dalam zaman Yunani kuno yang 
pekerjaannya menjemput dan mengantar anak-anak ke dan dari sekolah. Selain itu, di rumahnya anak tersebut selalu dalam pengawasan dan penjagaan para paedagogos. Istilah ini berasal dari kata paedos yang berarti anak, dan agogos yang berarti saya membimbing atau memimpin. (Modul Manajemen Pendidikan Non Formal. Sulfemi, Wahyu Bagja) [2018/01]

2. Standar Proses Pendidikan

Standar proses pendidikan dapat diartikan sebagai suatu bentuk teknis yang merupakan acuan atau kriteria yang dibuat secara terencana dalam pelaksanaan pembelajaran. Standar proses pendidikan adalah standar nas ional pendidikan yang berkaitan dengan pelaksanaan pembelajaran pada satuan pendidikan unruk mencapai standar kompetensi lulusan nasional. Dikatakan bahwa standar proses pendidikan adalah kriteria minimal tentang system pendidikan diseluruh wilayah pendidikan Negara Kesatuan Republik Indonesia. Ada beberapa standarr lainnya yang ditetapkan dalam standarr nasional yaitu standar kompetensi lulusan, standar isi, standar sarana dan prasarana, standar pengelolaan, standar pembiayaan, dan standar penilaian.

Standar proses KTSP diatur dalam permendikbud nomor 41 tahun 2007, sedangkan standar proses kurikulum 2013 diatur dalam permendikbud nomor 65 tahun 2013. Kedua peraturan menteri ini masingmasing menjadi dasar hukum pelaksanaan pembelajaran pada satuan pendidikan dasar dan menengah untuk mencapai kompetensi lulusan. Dalam hal ini, dengan berlakunya permendikbud nomor 65 tahun 2013 maka permendikbud nomor 41 tahun 2007 dinyatakan tidak berlaku lagi.

Pada tahapan ini standar kompetensi lulusan menjadi semacam kerangka konseptual tentang sebuah proses dan sasaran pembelajaran yang harus dicapai oleh lembaga pendidikan.

Karena itu pada kurikulum 2013, pada tataran proses pembelajaran dan untuk memperkuat pendekatan ilmiahh (scientific), tematik terpadu (tematik antarmata pelajaran), dan tematik (dalam suatu mata pelajaran) 
akan mengupayakan agar para guru mampu menerapkan pembelajaran berbasis penyingkapan/penelitian (discovery/inquiry learrning). Hal ini bertujuan untuk mendorong kemampuan peserta didik untuk menghasilkan karya kontekstual, baik individu maupun kelompok. Maka sangat disarankan menggunakan pendekatan pembelajaran yang menghasilkan karya berbasis pemecahan masalah (project based learning).

Standar proses berisi kriteria minimal proses pembelajaran pada satuan pendidikan dasar dan menengah di seluruh wilayah Indonesia. Standar proses ini berlaku untuk jenjang pendidikan dasar dan menengah pada jalur formal, baik pada sistem paket maupun pada sistem kredit semester.

3. Standar proses meliputi beberapa tahapan untuk terlaksanakannya proses pembelajaran yang efektif dan efisien, yaitu :

a) Perencanaan Proses Pembelajaran

Sesuai dengan Permendikbud No 81 Tahun 2013 tentang implementasi kurikulum, perencanaan proses pembelajaran meliputi silabus dan Rencana Pelaksanaan Pembelajaran (RPP) yang memuat Identitas mata pelajaran, Standar Kompetensi (SK), Kompetensi Dasar (KD), indikator pencapaian kompetensi, penilaian hasil belajar, tujuan pembelajaran, dan sumber belajar.

1) Silabus

Sesuai dengan Salinan Lampiran Permendikbud No 65 Tahun 2013 tentang standar proses, silabus sebagai acuan pengembangan RPP memuat identitas mata pelajaran, SK, KD, materi pembelajaran, kegiatan pembelajaran, indikator pencapaian kompetensi, tujuan pembelajaran, dan sumber belajar. Silabus dikembangkan oleh satuan pendidikan berdasarkan standar isi dan standar kompetensi lulusan, serta panduan penyusunan kurikulum 2013. Silabus digunakan sebagai acuan dalam pengembangan RPP. Dalam pelaksanaannya, pengembangan silabus dapat dilakukan 
oleh para guru secara mandiri atau kelompok dalam sebuah sekolah/madrasah atau beberapa sekolah, kelompok musyawwarah guru mata pelajaran (MGMP) atau pusat kegiatan guru (PKG), dan dinas pendidikan.

2) Rencana Pelaksanaan Pembelajaran (RPP)

Sesuai dengan Salinan Lampiran Permendikbud No 65 Tahun 2013 tentang standar proses, Rencana Pelaksanaan Pembelajaran (RPP) adalah rencana kegiatan pembelajaran tatap muka untuk satu pertemuan atau lebih. RPP dikembangkan dari silabus untuk mengarahkan kegiatan pembelajaran peserta didik dalam upaya mencapai Kompetensi Dasar (KD). Setiap pendidik pada satuan pendidikan berkewajiban menyusun RPP secara lengkap dan sistematis agar pembelajaran berlangsung secara interaktif, inspiratif, menyenangkan, menantang, efisien, memotivasi peserta didik untuk berpartisipai aktif, serta memberikan ruang yang cukup bagi prakarsa, kreativitas, dan kemandirian sesuai dengan bakat, minat, dan perkembangan fisik serta psikologis peserta didik. RPP disusun berdasarkan KD atau sub tema yang dilaksanakan dalam satu kali pertemuan atau lebih.

Sesuai dengan salinan lampiran Permendikbud No 65 Tahun 2013 tentang standar proses, komponen RPP terdiri atas :

(a) Identitas sekolah yaitu nama satuan pendidikan.

(b) Identitas mata pelajaran.

(c) Kelas/semester.

(d) Materi pokok.

(e) Alokasi waktu.

(f) Tujuan pembelajaran yang dirumuskan sesuai KD.

(g) Kompetensi dasar dan indikator pencapaian kompetensi.

(h) Materi pembelajaran.

(i) Metode pembelajaran. 
(j) Media pembelajaran.

(k) Sumber belajar.

(l) Penilaian hasil pembelajaran.

Prinsip penyusunan RPP menurut salinan lampiran Permendikbud No 65 Tahun 2013 tentang standar proses, adalah sebagai berikut :

(a) Perbedaan individual peserta didik antara lain kemampuan awal, tingkat intelektual, bakat, potensi, minat, motivasi belajar, kemampuan sosial, emosi, dll.

(b) Partisipasi aktif peserta didik.

(c) Berpusat pada peserta didik untuk mendorong semangat belajar, motivasi, minat, kreattivitas, inisiatif, inspirasi, inivasi dan kemandirian.

(d) Pengembangan budaya mambaca dan menulis yang dirancang untuk mengembangkan kegemaran membaca.

(e) Pemberian umpan balik.

(f) Penekanan pada keterkaitan dan keterpaduan antara $\mathrm{KD}$, materi pembelajaran, kegiatan pembelajaran, indikator pencapaian kompetensi, penilaian, dan sumber belajar.

(g) Mengakomodasi pembelajaran tematik terpadu.

(h) Penerapan teknologi informasi dan komunikasi secara terintegritasi, sistematis, dan efektif sesuai dengan situasi dan kondisi.

b) Pelaksanaan proses pembelajaran

Sesuai dengan salinan lampiran Permendikbud No 65 Tahun 2013 tentang standar proses, berikut adalah beberapa hal yang berkaitan dengan pelaksanaan pembelajaran :

1) Persyaratan pelaksanaan proses pembelajaran

(a) Alokasi waktu jam tatap muka pelajaran. 
(b) Buku teks pelajaran.

(c) Penetapan beban belajar .

(d) Pengelolaan kelas.

2) Prinsip pelaksanaan pembelajaran

Secara prinsip, kegiatan belajar merupakan proses pendidikan yang memberikan kesempatan kepada peserta didik untuk mengembangkan potensi mereka menjadi kemampuan yang semakin meningkat dalam sikap, pengetahuan, dan keterampilan yang diperlukan dirinya untuk hidup dan untuk bermasyarakat, berbangsa serta berkontribusi pada kesejahteraan hidup umat manusia. Oleh karena ituu, pembelajaran diarahkan untuk memberdayakan semua potensi peserta didik menjadi kompetensi yang diharapkan.

3) Metode pembelajaran dalam kurikulum 2013

(a) Pendekatan scientific pada proses pembelajaran

(1) Pengertian

Pelaksanaan proses pembelajaran kurikulum 2013 menggunakan pendekatan Scientific. Pembelajaran dengan metode ini dapat didefinisikan sebagai pembelajaran yang dirancang sedemikian rupa sehingga peserta didik secara aktif mengkonstruk konsep, hukum atau prinsip melalui tahapan-tahapan mengamati (untuk mengidentifikasi atau menemukan masalah), merumuskan masalah, mengajukan atauu merumuskan hipotesis, mengumpulkan data, menarik kesimpulan dan mengomunikasikan konsep, hukum atau prinsip yang ditemukan (kemendikbud, 2013). Pada pelaksanaannya pendekatan ini menekankan pada lima aspek penting, yaitu mengamati, menanya, mencoba, menalar dan komunikasi.

(2) Keterkaitan antara langkah pembelajaran dengan kegiatan belajar dan maknanya. 
(3) Karakteristik pembelajaran dengan metode saintifik. Sebagai berikut :

(a) Berpusat pada siswa.

(b) Melibatkan pada keterampilan proses sains dalam mengonstruksi konsep, hukum, atau prinsip.

(c) Melibatkan proses-proses kognitif yang potensial.

(d) Dapat mengembangkan karakter siswa.

(4) Tujuan pembelajaran dengan metode saintifik

(a) Untuk meninkatkan kemampuan intelektual.

(b) Untuk membentuk kemampuan siswa dalam menyelesaikan suatu masalah secara sistematik.

(c) Terciptanya kondisi pembelajaran yang menyebabkan siswa merasa bahwa belajar itu merupakan suatu kebutuhan.

(d) Untuk mengembangkan karakter siswa.

(5) Prinsip-prinsip pembelajaran saintifik

(a) pembelajaran berpuat pada siswa.

(b) Pembelajaran membentuk syudent self concept.

(c) Pembelajaran mendorong terjadinya peningkatan kemampuan berfokor siswa.

b) Penilaian hasil dan proses pembelajaran.

Penilain proses pembelajaran menggunakan pendekatan penilaian otentik yang menilai kesiapan siswa, proses, dan hasil belajar secara utuh. Keterpaduan penilaian ketiga komponen tersebut akan menggambarkan kapasitas, gaya, dan perolehan belajar siswa atau bahkan mampu menghasilkan dampak instruksional dan dampak pengiring dari pembelajaran.

Hasil penilaian otentik dapat digunakan oleh guru untuk merencakan program perbaikan (remedial), pengayaan, atau pelayanan konseling. Selain itu, hasil penilaian otentik dapat 
digunakan sebagai bahan untuk memperbaiki proses pembelajaran sesuai dengan Standar Penilaian Pendidikan. Evaluasi proses pembelajaran dilakukan saat proses pembelajaran dengan menggunakan alat : angket, observasi, catatan, dan refleksi.

c) Pengawasan proses pembelajaran

Pengawasan proses pembelajaran dilakukan melalui kegiatan pemantauan, supervisi, evaluasi, pelaporan, serta tindak lanjut secara berkala dan berkelanjutan. Pengawasan proses pembelajaran dilakukan oleh kepala satuan pendidikan dan pengawasan.

1) Prinsip pengawasan

Pengawaan dilakukan dengan prinsip objektif dan transparan guna peningkatan mutu secara berkelanjutan dan menetapkan peringkat akreditasi.

2) Sistem dan entitas pengawasan

Sistem pengawaan internal dilakukan oleh kepala sekolah, pengawas, dinas pendidikan dab lembaga penjaminann mutu pendidikan.

(a) Kepala sekolah, pengawas dan lembaga penjamin mutu pendidikan melakukan pengawasan dalam rangka peningkatan mutu.

(b) Kepala sekolah dan pengawas melakukan pengawasann dalam bentuk supervisi akademik dan supervisi manajerial.

3) Proses pengawasan

(a)Pemantauan

Pemantauan proses pembelajaran dilakukan pada tahap perencaaan, pelaksanaan, dan penilaian hasil pembelajaran. Pemantauan dilakukan melalui diskusi 
kelompok, pengamatan, pencatatan, perekaman, wawancara, dan dokumentasi.

(b)Supervisi

Supervisi proses pembelajaran dilakukan pada tahap perencanaan, pelaksanaan, dan penilaian hasil pembelajaran yang dilakukan melalui antara lain, pemberian contoh, diskusi,, konsultasi, atau pelatihan.

(c)Pelaporan

Hasil kegiatann pemantauan, supervisi, dan evaluasi proes pembeljaran disusun dalam bentuk laporan kepentingan tindak lanjut pengembangan keprofesionalann pendidik secara berkelanjutann.

(d)Tindak lanjut

Tindak lanjut hasil pengawasan dilakukan dalam bentuk :

(1) Penguatan dann penghargaan kepada guru yang menunjukkan kinerja yang memenuhi atau melampaui standar.

(2) Pemberian kesempatan kepada guru uuntuk mengikuti program pengembangan keprofesioonalan berkelanjutan. 


\section{Soal dan Jawaban}

\section{A. Pilihan Ganda}

1. Apa yang dimaksud dengan Permendikbud...

a. Pemerintah Pendidikan dan Budaya

b. Peraturan Menteri Pendidikan dan Budaya

c. Persatuan Menteri Pendidikan dan Budaya

d. Permerintah Mencari Pendukung dan Budaya

2. Nomor dan tahun berapa Permendikbud standar proses...
a. No. 56 Tahun 2014
b. No. 65 Tahun 2015
c. No. 18 Tahun 2013
d. No. 65 Tahun 2013

3. Sebelum adanya Permendikbud No. 65 Tahun 2013, Standar Proses tadinya berada di No dan Tahun...
a. No. 41 Tahun 2007
b. No. 41 Tahun 2013
c. No. 14 Tahun 2009
d. No. 14 Tahun 2014

4. Apa yang dimaksud dengan "Discovery/Inquiry Learning"...
a. Penyingkapan/penelitian
b. Penelitian/Wawasan
c. Pengetahuan/Penyingkapan
d. Wawasan/Penelitian

5. Dalam standar proses ada empat tahapan untuk terlaksanakannya proses pembelajaran yang efektif dan efisien, diantaranya adalah...
a. Persyaratan pelaksanaan belajar
b. Penerapan pelaksanaan pembelajaran
c. Pelaksanaan proses pembelajaran
d. Proses pembelajaran yang efektif dan efisien

6. Apa yang dimaksud dengan RPP... 

a. Rencana Pembelajaran Pelaksanaan
b. Rencana Pelaksanaan Pembelajaran
c. Rencana Pembimbingan Pembelajaran
d. Rencana Penilaian Pembelajaran

7. Apa yang dimaksud dengan $\mathrm{KD}$...
a. Komunukasi Daerahh
b. Konsumen Daerah
c. Kompetensi Daerah
d. Kompetensi Dasar

8. Di bawah ini yang termasuk ke dalam proses pelaksanaan pembelajaran adalah...
a. Persyaratan pelaksanaan proses pembelajaran
b. Prinsip pelaksanaan pembelajaran
c. Metode pembelajaran dalam kurikulum 2013
d. Semua jawaban benar

9. Ada berapa komponen dalam RPP...
a. 12 komponen
b. 13 komponen
c. 14 komponen
d. 15 komponen

10. Proses pengawasan pembelajaran dilakukan dengan cara? Kecuali.
a. Pemantauan
b. Supervisi
c. Wawancara
d. Evaluasi dan Pelaporan

\section{B. Essay}

1. Jelaskan apa yang dimaksud dengan standar proses?

2. Tuliskan pengertian standar proses menurut Kamus Besar Bahasa Indonesia (KBBI)?

3. Apa yang dimaksud dengan RPP ? Dan jelaskan. 
4. Sebutkan 5 prinsip penyusunan RPP menurut PERMENDIKBUD No. 65 Tahun 2013?

5. Tuliskan komponen-komponen dalam RPP?

\section{Jawaban}

a) Pilihan Ganda
1. B
6. B
2. D
7. D
3. A
8. D
4. A
9. A
5. C
10. $\mathrm{C}$

b) Essay

1. Standar proses adalah sebuah pedoman atau tahapan langkahlangkah bagi para guru saat mereka memberikan pembelajaran dalam kelas, dengan harapan proses pendidikan yang berlangsung bisa efektif, efesien dan inofatif. Sehingga beberapa target atau kriteria mengenai kompetensi lulusan dapat tercapai dengan sempurna.

2. Standar proses menurut KBBI adalah suatu ukuran tertentu yang menjadi dasar penilaian atau penetapan sesuatu, kaitannya dengan pelaksanaan pembelajaran guna mencapai kompetensi lulusan.

3. RPP adalah Rencana Pelaksanaan Pembelajaran.

Yang artinya adalah Rencana kegiatan pembelajaran tatap muka untuk satu pertemuan atau lebih.

4. - Perbedaan individual peserta didik antara lain kemampuan awal, tingkat intelektual, bakat, potensi, minat, motivasi belajar, kemampuan sosial, emosi, dll.

- $\quad$ Partisipasi aktif peserta didik. 
- Berpusat pada peserta didik untuk mendorong semangat belajar, motivasi, minat, kreattivitas, inisiatif, inspirasi, inivasi dan kemandirian.

- Pengembangan budaya mambaca dan menulis yang dirancang untuk mengembangkan kegemaran membaca.

- Pemberian umpan balik.

5. - Identitas sekolah yaitu nama satuan pendidikan.

- Identitas mata pelajaran.

- Kelas/semester.

- Materi pokok.

- Alokasi waktu.

- Tujuan pembelajaran yang dirumuskan sesuai KD.

- Kompetensi dasar dan indikator pencapaian kompetensi.

- Materi pembelajaran.

- Metode pembelajaran.

- Media pembelajaran.

- Sumber belajar.

- Penilaian hasil pembelajaran. 


\section{Daftar Pustaka}

https://id.m.wikipedia.org/wiki/Standar_teknis

https://www.kompasiana.com/arits.ilham/54f73fffa33311590f8b47ab/standarproses-pendidikan-nasional-dan-penerapannya-dalam-sistem-pendidikandi-sekolah

Indrawan, Sholeh. (2014). Iplementasi Standar Proses Kurikulum 2013 Di Jurusan Teknik Kendaraan Ringan SMK Negeri 1 Sedayu. Yogyakarta : Skripsi. (23-31).

Sulfemi, Wahyu Bagja. (2016). Perundang-Undangan Pendidikan. Bogor : Program Studi Administrasi Pendidikan STKIP Muhammadiyah Bogor.

Sulfemi, Wahyu Bagja. (2018). Modul Manajemen Pendidikan Non Formal. Bogor : STKIP Muhammadiyah Bogor.

Sulfemi, Wahyu Bagja. (2019). Manajemen Sekolah. Bogor : Program Studi Administrasi Pendidikan STKIP Muhammadiyah Bogor. 